\title{
Social Commerce Constructs and Buyer-Seller Relationship Quality as a predictor of Intention to Co-Creation in Branding
}

\author{
Prasittichai Narakorn ${ }^{1} \&$ Tummatinna Seesupan ${ }^{1}$ \\ ${ }^{1}$ Faculty of Management Science, Pibulsongkram University, Thailand \\ Correspondence: Tummatinna Seesupan, Faculty of Management Science, Pibulsongkram University, Thailand. \\ Tel: 94-615-9656. E-mail: tummatinna@psru.ac.th
}

Received: Nov. 10, 2018

doi:10.5539/mas.v13n2p169

\author{
Accepted: Nov. 28, 2018 \\ Online Published: January 22, 2019
}

URL: https://doi.org/10.5539/mas.v13n2p169

\begin{abstract}
The main objective of this research was to examine the Rating and Reviews, Forums and Communities, and BuyerSeller Relationship Quality as factors influencing the Intention to Co-creation in Branding. The researchers used quantitative method which involved empirical research. A questionnaire was used to collect data from 512 customers who buy products from online business. The researcher did data analysis by percentage, mean, SD, and Structural Equation Model analysis by AMOS.

Referring to research findings, it was found as follows (1) the model for Intention to Co-Creation in Branding which includes Rating and Reviews, Forums and Communities, and Buyer-Seller Relationship Quality was aligned with the empirical data at good level $\left(\chi^{2}=78.903, \mathrm{df}=66, \mathrm{p}\right.$-value $=.133, \chi^{2} / \mathrm{df}=1.196, \mathrm{GFI}=.979, \mathrm{IFI}=.996$, $\mathrm{CFI}=.996$, RMSEA $=.020$ ) (2) the factor of Rating and Reviews, Forums and Communities, and Buyer-Seller Relationship Quality affected the Intention to Co-Creation in Branding at statistical level of significance $(\mathrm{p}<.05)$ and all factors predicts the Intention to Co-Creation in Branding at $44.10\left(\mathrm{R}^{2}=0.441\right)$.
\end{abstract}

Keywords: Rating and Reviews, Forum and Communities, Buyer-Seller Relationship Quality, Intention to CoCreation in Branding

\section{Introduction}

Traditional market mainly focuses on the ability of seller in producing and providing products to buyers without understanding the customer needs. This can also be called Company-Centric Approach. This method does neither serve the customer needs nor focus on the operation efficiency rather than the customer needs. In this method, it could be found that most information is provided by the seller with few feedbacks from customer (Chen \& Shen, 2015).

Nowadays, the communication technology in social network really helps people connect and share information and experience among each other more effectively which significantly leads to co-creation that definitely serves the customer needs (Prahalad \& Ramaswamy, 2004; Narakorn, 2015). This remarkable phenomenon provides the great opportunity for seller in creating value that gains more competitive advantages from competitors (Porter \& Donthu, 2008), especially those who take the Social Commerce Constructs in action (Hajli, 2015; Narakorn \& Seesupan, 2018) e.g. Rating and Reviews, Forum and Communities which are developed in Social Network Site to apply in business context which buyers can create content and share experience by real-time transaction via "Like", "Share", or "Comment" in social networks -- Facebook, Line, Twitter, Instagram (Liang \& Turban, 2012). By these channels, the seller really understands the real needs of customers which creates the Intention to CoCreation in Branding (Wang \& Hajli, 2014).

However, due to the overwhelming newsfeeds in social network, the buyer and seller cannot distinguish and validate the information which they have gained daily which triggers that the information cannot also be used as reference. Therefore, the Buyer-Seller Relationship Quality plays a major role in filtering newsfeeds in order to ensure the content validity which significantly affects the Intention to Co-Creation in Branding (Prahalad \& Ramaswamy, 2004; Narakorn, 2015). Additionally, in the digital era which the big data could power overtremendously, this requires buyer and seller to consider and validate the information to mitigate any risks. This is relatively called the Intention to Co-Creation in Branding (Wang \& Hajli, 2014).

Additionally, Social Commerce Constructs such as Rating and Reviews, and Forums and Communities are newly- 
developed and grows rapidly. However, these mechanisms are not well-structured and not standardized, as well as naturally the online platform does not provide opportunity to buyer and seller to meet at face-to-face, most entrepreneur have been struggling to build the Intention to Co-Creation in Branding which triggers to loss in business development and to build customer relationship (Yahia, AI-Neama, \& Kerbache, 2018). Also, the relationship quality, trust, and commitment between buyer and seller have been gradually weakened (Morgan \& Hunt, 1994).

Also, it could be found that there is research gap in Social Commerce Constructs such as Rating \& Reviews and Forums \& Communities, Buyer-Seller Relationship Quality, and the Intention to Co-Creation in Branding. In order to fulfill this gap, the researcher team do the literature and related research review by following the framework of Social Commerce Construct by Hajli (2014), Buyer-Seller Relationship Quality by Wang and Hajli (2014), and Intention to Co-Creation in Branding by Prahalad and Ramaswamy (2004).

The research question of this study was whether Rating and Review, Forums and Communities, Buyer-Seller Relationship Quality significantly affect and the Intention to Co-Creation in Branding. The research objective was to examine the Rating and Review, Forums and Communities, and Buyer-Seller Relationship Quality as factors influencing the Intention to Co-Creation in Branding.

\section{Theoretical Background and Hypothesis Development}

Our research model comprises four constructs: Rating \& Reviews and Forum \& Communities (Hajli, 2014; Hajli, 2015; Hajli, Lin, Featherman, \& Wang, 2014; Narakorn \& Seesupan, 2018) Buyer-Seller Relationship Quality (Morgan \& Hunt, 1994; Wang \& Hajli, 2014; Ogara, Koh, \& Prybutok, 2014) and Intention to Co-Creation in Branding (Prahalad \& Ramaswamy, 2004; Wang \& Hajli, 2014) as following detail.

\subsection{Rating and Reviews}

Hajli (2014) argued that the Product Rating and Reviews are ones of Social Commerce Constructs which buyers can share their opinions after using product by posting in the online social network that really helps rank the interest and reliability towards products and consequently helps other customers make decision to purchase products more easily (Hajli, 2015; Hajli et al., 2014; Narakorn \& Seesupan, 2018). The main reason is that buyers trust on the member and open for opinion and review by their online friends rather than sellers (Narakorn, 2018).

The Product Rating and Reviews as exogenous variable $(\xi)$ consist of three observed variables (1) social network friends directly do the rating and review product (RAT1) (2) social network friends reliably do the rating (RAT2) and (3) social network friends share experience in product with reliable opinion (RAT3) (Hajli, 2015; Hajli \& Sims, 2015; Hew, Lee, Ooi, \& Lin, 2016)

\subsection{Buyer-Seller Relationship Quality}

The Buyer-Seller Relationship Quality refers to the concept of relationship marketing which aims at sustaining the relationship between buyer and seller as long as possible (Hajli, 2014) in order to decrease the transaction cost as well as strengthen the long-term customer loyalty. The Buyer-Sell Relationship Quality as composed of three components (1) trust in doing business with transparency, integrity, and privacy (2) commitment between buyer and seller to keep and follow the agreement with sincerity (3) customer satisfaction at post-online transaction at higher result from expectation such as coordination and contact via social network (Dholakia \& Zhao, 2008; Kirk, Chiagouris, Gopalakrishna, 2012; Ogara, Koh, Prybutok, 2014).

The Buyer-Seller Relationship Quality as endogenous variable $(\eta)$ consists of four observed variables (1) seller strongly keeps promise to buyer (RQ1) (2) buyer is satisfied with contacting in the online community platform provided by seller (RQ2) (3) buyer is willing to contact seller in online community platform (RQ3) and (4) buyer is happy with contacting seller in the online community platform (RQ4). From literature review, the researcher team developed the research hypothesis as follows (Wang \& Hajli, 2014; Zhang, Benyoucef, Zhao, 2016).

H1: The Product Rating and Reviews from online shopping site will positively influence to the Buyer-Seller Relationship Quality

\subsection{Intention to Co-Creation in Branding}

The Intention to Co-Creation in Branding refers to the communication between buyer and seller which creates values to serve the individual needs of each buyer. This concept follows the concept of value creation which the organization serves the real customer's needs by utilizing organization's strength which is really unique and gains more competitive advantage from others (Prahalad \& Ramaswamy, 2004; Narakorn, 2015). Cayla and Arnould (2008) indicated that the experience in former products really helps developing the understanding on buyer and increase potential in creating values of employees in organization (Seesupan \& Narakorn, 2018; Vargo \& Lush, 
2004).

The Intention to Co-Creation in Branding as endogenous variable $(\eta)$ consists of four observed variables (1) buyer intentionally recommends the information on product to social network friends (CO1) (2) buyer shares the experience in product social network friends (CO2) (3) buyer purchases product by recommendation from social network friends (CO3) and (4) buyer always asks opinion from social network friends prior to purchase (CO4). From literature review, the researcher team developed the research hypothesis as follows (Wang \& Hajli, 2014; Zhang et al., 2016).

H2: The Product Rating and Reviews from online shopping site will positively influence to the Intention to Co-Creation in Branding.

\subsection{Forums and Communities}

Forums and Communities is regarded as one of Social Commerce Constructs (Hajli, 2015) as user-generate content in the online community. Creating forums and communities is the online public space where everyone can communicate and interacts with each other on information on product such as Facebook, Instagram, Twitter (Ahmad \& Laroche, 2016; Bai, You, \& Dou, 2015; Guo \& Zhou, 2016; Jung \& Cho, 2016)

Forums and Communities as exogenous variable $(\xi)$ consist of three observed variables (1) social network friends directly create the forums (FOR1) (2) social network friends create the forum with reliable topic and content (FOR2) and (3) social network friends share the reliable experience in forums (FOR3) (Hajli, 2015; Hew et al., 2016). From literature review, the researcher team developed the research hypothesis as follows (Wang \& Hajli, 2014; Zhang et al., 2016):

H3: The Product Forums and Communities from online shopping site will positively influence the BuyerSeller Relationship Quality.

H4: The Product Forums and Communities from online shopping site will positively influence the Intention to Co-Creation in Branding.

H5: The Buyer-Seller Relationship Quality will positively influence to the Intention to Co-Creation in Branding in online shopping.

\section{Method}

In this study, the researcher team applied the quantitative research by directly collecting data from the 512 online buyers nationwide as sample group in order to validate the research hypothesis.

\subsection{Questionnaire}

The hard-copied questionnaire was utilized in this research by dividing into three parts (1) basic information of targeted participants (2) general information in using online business and (3) Rating and Reviews, Forums and Communities, and Buyer-Seller Relationship Quality, and Intention to Co-Creation in Branding.

\subsection{Factor Analysis and Reliability Testing}

Factor Analysis and Reliability Testing were conducted to ensure that all research constructs are reliable. The researcher team validated the content validity by the corrected item-total correlation and the objectives by three professionals in E-commerce. Also, the questionnaire was tested for reliability to the pilot group $(\mathrm{n}=30)$ before distributing to the sample group $(\mathrm{n}=512)$. The computation of Cronbach's alpha was done using a reliability analysis to ensure consistency of the survey data (Wang \& Hajli, 2014). The Cronbach's alpha is based on average correlation of items within the test. A common rule of thumb is that indicators should have a Cronbach's alpha of at least 0.7 to judge the set of items as reliable (Nunnally, 1978). The results for these two tests are presented in Table 1.

Table 1. Summary of factor analysis and Cronbach's alpha test

\begin{tabular}{|c|c|c|c|c|}
\hline Latent Variables/ Observed Variables & $\begin{array}{c}\text { Factor } \\
\text { Loading }\end{array}$ & $\begin{array}{c}\text { Cronbach's } \\
\text { Alpha }\end{array}$ & AV & $\mathrm{CR}$ \\
\hline Rating and Reviews (Hajli, 2014) & & 0.788 & 0.557 & 0.790 \\
\hline RAT1 Social network friends directly do the rating \& review product & 0.738 & & & \\
\hline RAT2 Social network friends reliably do the rating & 0.778 & & & \\
\hline RAT3 Social network friends share experience in product with reliable opinion & 0.721 & & & \\
\hline Forum and Communities (Hajli, 2014) & & 0.825 & 0.610 & 0.824 \\
\hline FOR1 Social network friends directly create the forums & 0.804 & & & \\
\hline FOR2 Social network friends create the forum with reliable topic and content & 0.766 & & & \\
\hline
\end{tabular}


FOR3 Social network friends share the reliable experience in forums

Buyer-Seller Relationship Quality (Wang \& Hajli, 2014)

RQ1 seller strongly keeps promise to buyer

RQ2 buyer is satisfied with contacting in the online community platform provided by seller

RQ3 buyer is willing to contact seller in online community platform

RQ4 buyer is happy with contacting seller in the online community platform

Intention to Co-Creation in Branding (Wang \& Hajli, 2014)

$\mathrm{CO} 1$ buyer intentionally recommends the information on product to online friends

$\mathrm{CO} 2$ buyer shares the experience in product $\mathrm{t}$ online friends

$\mathrm{CO} 3$ buyer purchases product by recommendation from online friends

CO4 buyer always asks opinion from online friends prior to purchase product

$\begin{array}{llll}0.748 & 0.748 & 0.555 & 0.832 \\ 0.636 & & & \\ 0.764 & & & \\ & & & \\ 0.784 & & & \\ 0.786 & 0.859 & 0.599 & 0.856 \\ & & & \\ 0.826 & & & \\ 0.814 & & & \\ 0.759 & & & \\ 0.689 & & & \end{array}$

Description: Factors loading ranged from 0.635 to 0.824 , Cronbach's alpha was calculated for each factor, and each was found reliable $(0.788,0.825,0.748$, and 0.859 respectively). These four factors were: Rating \& Reviews, Forums \& Communities, Buyer-Seller Relationship Quality, and Intention to Co-Creation in Branding.

\section{Results}

\subsection{Respondent Demographics}

From the sample group of 512 online buyers, it was found that most participants were female $(74.80 \%)$ were 29 years-old in average, held Bachelor's Degree, followed by Master Degree, and below Bachelor Degree respectively, had monthly income in the range of 307.23 - 614.41 US Dollar, followed by that of 614.42 - 921.63 US Dollar, and Under 307.22 US Dollar respectively, were governmental officers / government employees, followed by student/ college student, and company employee respectively (show Table 2).

As for the respondents'opinion, it could be found that the Rating and Reviews is ranked as the high level (3.58), followed by Buyer-Seller Relationship Quality at high level (3.56), Forum and Communities at high level (3.55), and Intention to Co-Creation in Branding (3.42) respectively.

Table 2. Number and percentage of respondent $) \mathrm{n}=512($

\begin{tabular}{llcc}
\hline Demographic Characteristics & Number (people) & Percentage \\
\hline Gender & Male & 129 & 25.20 \\
Education & Female & 383 & 74.80 \\
& Under Bachelor's Degree & 84 & 16.40 \\
& Bachelor's Degree & 304 & 59.40 \\
& Master's Degree & 115 & 22.50 \\
Income/month & Above Master Degree & 9 & 1.80 \\
& Under 307.22 US Dollar & 110 & 21.50 \\
& 307.23 - 614.41 US Dollar & 193 & 37.70 \\
& 614.42 - 921.63 US Dollar & 124 & 24.20 \\
& 921.64 - 1,228.85 US Dollar & 49 & 9.60 \\
1,228.86 - 1,536.07 US Dollar & 18 & 3.50 \\
& Above 1,536.08 US Dollar & 18 & 3.50 \\
& Governmental officers/government employees & 194 & 37.90 \\
& Company employees & 126 & 24.60 \\
& Student/ college student & 136 & 26.60 \\
& Entrepreneur & 39 & 7.60 \\
& Others & 17 & 3.30 \\
\hline
\end{tabular}

Note: 1 US Dollar $=32.55$ THB

\subsection{Structural Equation Modeling}

As for result of factors influencing the Intention to Co-Creation in Branding, it is analyzed by Structural Equation Modeling by AMOS and found that the model of Intention to Co-Creation in Branding which consists of Rating and Reviews, Forums and Communities, and Buyer-Seller Relationship Quality is in line with the empirical data at good level $\left(\chi^{2}=78.903, \mathrm{df}=66, \mathrm{p}\right.$-value $=.133, \chi^{2} / \mathrm{df}=1.196, \mathrm{GFI}=.979, \mathrm{IFI}=.996, \mathrm{CFI}=.996$, RMSEA 
$=.020)$. Therefore, it could be concluded that the model of the Intention to Co-Creation in Branding is aligned to the model specified by research conceptual framework at good level (show in Figure 1).

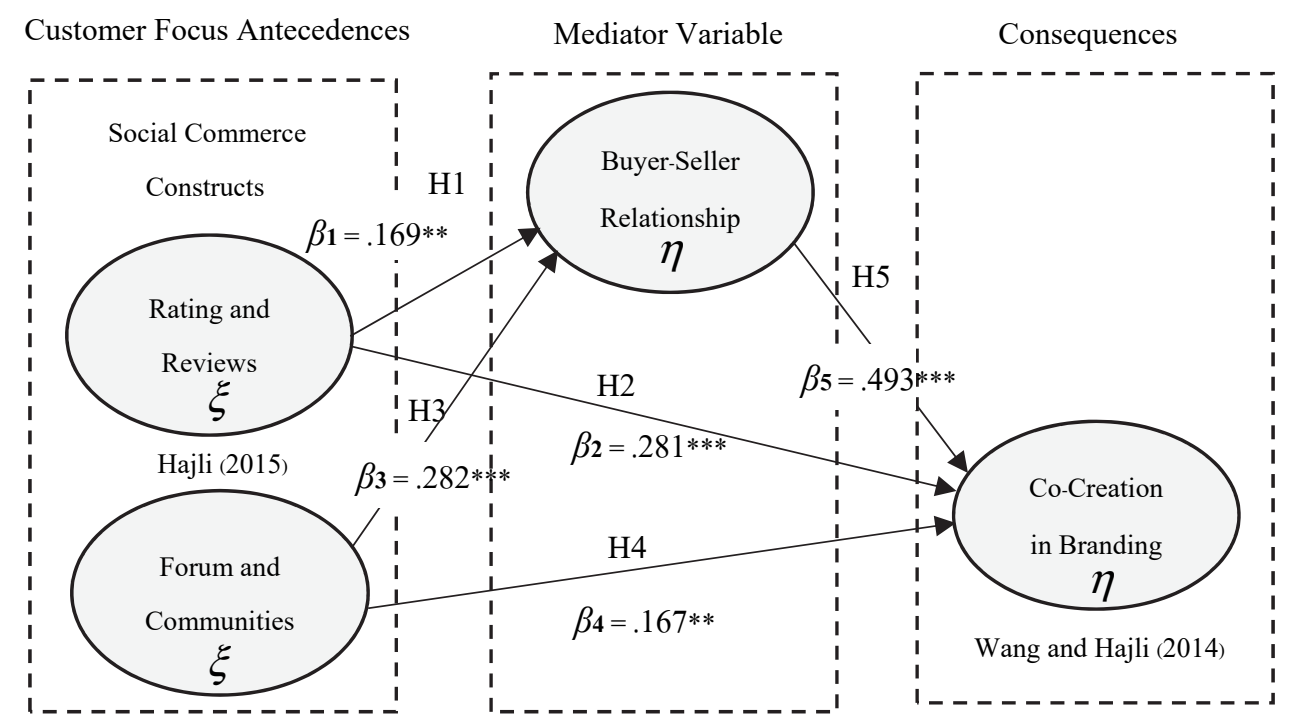

Figure 1. Research conceptual framework (post-model adjustment)

According to Table 3, it could be seen as follows: H1-Rating and Reviews had significantly influence to BuyerSeller Relationship Quality $(\beta 1=.169, \mathrm{t}=3.223, \mathrm{p}<0.01) ; \mathrm{H} 2-$ Rating and Reviews had significant influence to the Intention to Co-Creation in Branding $(\beta 2=.281, \mathrm{t}=3.999, \mathrm{p}<0.001)$; H3-Forums and Communities had significantly influence to Buyer-Seller Relationship Quality $(\beta 3=.282, \mathrm{t}=5.827, \mathrm{p}<0.001)$; H4-Forums and Communities had significantly influence to the Intention to Co-Creation in Branding $(\beta 4=.167, \mathrm{t}=2.604, \mathrm{p}<$ 0.01); and H5-Buyer-Seller Relationship Quality had significantly influence to the Intention to Co-Creation in Branding $(\beta 5=.493, \mathrm{t}=5.868, \mathrm{p}<0.001)$.

Table 3. Result of Hypothesis Testing

\begin{tabular}{llcll}
\hline & \multicolumn{1}{c}{ Path Analysis } & Path Coefficient & $t$-value & Result \\
\hline H1 & Rating \& Reviews $\rightarrow$ Buyer-Seller Relationship Quality & .169 & $3.223^{* *}$ & Support \\
H2 & Rating \& Reviews $\rightarrow$ Co-Creation in Branding & .281 & $3.999^{* * *}$ & Support \\
H3 & Forum \& Communities $\rightarrow$ Buyer-Seller Relationship Quality & .282 & $5.827^{* * *}$ & Support \\
H4 & Forum \& Communities $\rightarrow$ Co-Creation in Branding & .167 & $2.604^{* *}$ & Support \\
H5 & Relationship Quality $\rightarrow$ Co-Creation in Branding & .493 & $5.868^{* * *}$ & Support \\
\hline
\end{tabular}

Note: $(1) *$ refers to $\mathrm{p}<0.05$ and $1.96 \leq \mathrm{t}$-value $<2.576,(2) * *$ refers to $\mathrm{p}<0.01$ and $\mathrm{t}$-value $\geq 2.576$, (3) $* * *$ refers to $\mathrm{p}<0.001$ and $\mathrm{t}$-value $\geq 3.291$

As illustrated in Table 4, it could be found that Buyer-Seller Relationship Quality had the Total Effect (TE) to the Intention to Co-Creation in Branding ( $\mathrm{TE}=0.493)$, followed by Rating and Reviews ( $\mathrm{TE}=0.364)$, and Forums and Communities ( $\mathrm{TE}=0.306$ ) respectively. All factors were also the predictors to Intention to Co-Creation in Branding at $44.10 \%\left(\mathrm{R}^{2}=0.441\right)$.

Table 4. Influence of Antecedents to Dependent Variables

\begin{tabular}{lccccc}
\hline \multirow{2}{*}{ Latent Variable } & \multirow{2}{*}{$\mathrm{R}^{2}$} & Effect & \multicolumn{3}{c}{ Antecedent } \\
\cline { 4 - 6 } & & Rating \& Reviews & $\begin{array}{c}\text { Forum \& } \\
\text { Communities }\end{array}$ & $\begin{array}{c}\text { Buyer-Seller } \\
\text { Relationship Quality }\end{array}$ \\
\hline Relationship Quality & 0.335 & DE & 0.169 & 0.282 & 0.000 \\
& & IF & 0.000 & 0.000 & 0.000 \\
Co-Creation in & & TE & 0.169 & 0.282 & 0.000 \\
& 0.441 & DE & 0.281 & 0.167 & 0.493
\end{tabular}




\begin{tabular}{lllll} 
Branding & IE & 0.083 & 0.139 & 0.000 \\
& TE & 0.364 & 0.306 & 0.493 \\
\hline
\end{tabular}

Note: $\mathrm{DE}=$ Direct Effect, IE $=$ Indirect Effect, TE $=$ Total Effect

Table 5. Discriminant Validity

\begin{tabular}{lcccccc}
\hline & CR & AVE & (1) & (2) & (3) & (4) \\
\hline (1) Rating \& Reviews & 0.790 & 0.557 & 0.746 & & & \\
(2) Forum \& Communities & 0.824 & 0.610 & 0.642 & 0.781 & & \\
(3) Buyer-Seller Relationship Quality & 0.832 & 0.555 & 0.480 & 0.552 & 0.745 & \\
(4) Co-Creation in Branding & 0.857 & 0.599 & 0.543 & 0.535 & 0.577 & 0.774 \\
\hline
\end{tabular}

According to Table 5, it shows the discriminant validity from the measurement model of each variable construct which was measured without mixing to any other variables. If the value of $\sqrt{A V E}$ is higher than correlation between the latent variables in the same row, it indicates that the measurement model has the discriminant validity.

\section{Discussion}

The researcher team discussed the result of hypothesis testing at 5 key items as follows:

\subsection{Rating and Reviews had relationship to the Buyer-Seller Relationship Quality.}

In this study, it was found that Rating and Reviews had positive relationship to the Buyer-Seller Relationship Quality. This is in line with the findings from Wang and Hajli (2004) which proposed that Rating and Reviews affected the Buyer-Seller Relationship Quality. In addition, in this study, it could be found that the more reliable Rating and Reviews strengthens the Buyer-Seller Relationship Quality and the buyers are happy and impressed to seller's coordination in social network.

\subsection{Rating and Reviews had relationship to Intention to Co-Creation in Branding.}

In this research, it was found that Rating and Reviews had positive relationship to Intention to Co-Creation in Branding. This is aligned to the findings from Prahalad and Ramaswamy (2004) and Narakorn (2015) that indicated that the interaction between organization and customers can create new values which serves individual needs of customers and develop the uniqueness of product. Additionally, in this study, it was found that the more reliable rating increases the Intention to Co-Creation in Branding (Wang \& Hajli, 2014).

\subsection{Forums and Communities had relationship to Buyer-Seller Relationship Quality.}

In this study, it was found that Forums and Communities had positive relationship to Buyer-Seller Relationship Quality. This is in line with the findings from Hajli (2014) and Wang and Hajli (2014) which revealed that the online communities is the space where each member can share their opinion towards products. Moreover, in this research, it could be found that the more experience sharing in products among members strengthens the BuyerSeller Relationship Quality and the buyers since the buyers are more satisfied with the provided service (Narakorn, 2018; Zhang et al., 2016).

\subsection{Forums and Communities had relationship to Intention to Co-Creation in Branding.}

In this research, it was seen that Forums and Communities had positive relationship to Intention to Co-Creation in Branding. This is aligned to the findings from Hajli (2015) and Hew et al. (2016) which suggested that the experience sharing among members in online community could be verbal recommendation and create the new values. In this study, it was also found that the more experience sharing in products and creating the reliable forums increase the Intention to Co-Creation in Branding (Wang \& Hajli, 2014; Zhang et al., 2016).

\subsection{Buyer-Seller Relationship Quality had relationship to Intention to Co-Creation in Branding.}

In this study, it was found that Buyer-Seller Relationship Quality had positive relationship to Intention to CoCreation in Branding. This is in line with the findings from Prahalad and Ramaswamy (2004) and Wang and Hajli (2014) which proposed that the good relationship between organization and customers really maximizes the organization's strength to serve the individual needs of customer. Moreover, in this research, it was found that the buyers feel happy from contacting with sellers in online social network and leads to the recommendation towards products to others.

\section{Recommendations for online seller}

Referring to the buyer's opinion, it was found as follows: 1) the online seller should select Rating and Reviews as 
key mechanism to develop any new products 2 ) the online seller should collect data from the experience sharing on products for new product development and 3) the online seller should keep contact to the online buyer. 7 . Recommendation as National agenda

Public sector (1) it is advisable that the government should develop the infrastructure of communication to serve the E-commerce and social network site (2) it is suggested to set up the government agency to validate the information accuracy and ensure data privacy of online information to help people filter the reliable information.

Private sector (1) the entrepreneur whose have the shop as the only channel should increase the online channels to reach the target customer at anywhere and anytime which can build the customer loyalty in the long-term (2) the entrepreneur should integrate the knowledge and new technology to the government agency to gain more competitive advantage.

\section{Recommendation for further research}

1. In the next research, it is recommended that the researcher should apply the conceptual framework of Intention to Co-Creation in Branding to the real online business to validate the accuracy of the research

2. In this study, all independent variables including Rating and Reviews, Forums and Communities, and BuyerSeller Relationship Quality factors can be the predictors of Intention to Co-Creation in Branding at $44.10 \%$ whereas the other $55.90 \%$ are from other factors. As a result, in the next research, it is advisable to examine other factors which might affect the Intention to Co-Creation in Branding and do not focus in this research.

\section{References}

Ahmad, S. N., \& Laroche, M. (2016). Analyzing electronic word of mouth: A social commerce construct. International Journal of Information Management, 1-12.

Bai, Y., Yao, Z., \& Dou, Y. F. (2015). Effect of social commerce factors on user purchase behavior: An empirical investigation from renren.com. International Journal of Information Management, 35, 538-550.

Cayla, J., \& Arnould, E. J. (2008). A Cultural Approach to Branding in the Global Marketplace. Journal of Interactive Marketing, 16(4), 88-114.

Chen, J., \& Shen, X. L. (2015). Consumers' decision in social commerce context: An empirical; investigation. Decision Support Systems, 79, 55-64.

Comrey, A. L., \& Lee, H. B. (1992). A first course in factor analysis. Hillsdals, NJ: Erlbaum.

Dholakia, R. R., \& Zhao, M. (2008). Retail web site interactivity: How does it influence customer satisfaction and behavioral intentions?. International Journal of Retail \& Distribution Management, 37(10), 821-838.

Guo, B., \& Zhou, S. (2016). Understanding the impact of prior reviews on subsequent reviews: The role rating volume, variance and reviewer characteristics. Electronic Commerce Research and Application, 20, 147-158.

Gwebu, K. L., Wang, J., \& Guo, L. (2014). Continued usage intention of multifunctional friend networking services: A test of a dual-process model using Facebook. Decision Support Systems, 1, 1-12.

Hair, J. F., Black, W. C., Babin, B. J., \& Anderson, R. E. (2010). Multivariate Data Analysis, 7th ed., Prentice Hall, Upper Saddle River, NJ.

Hajli, N. (2014). The role of social support on relation quality and social commerce. Technology Forecasting \& Social Change, 87, 17-27.

Hajli, N. (2015). Social commerce constructs and consumer's intention to buy. International Journal of Information Management, 35, 183-191.

Hajli, N., \& Sims, J. (2015). Social commerce: The transfer of power from sellers to buyers. Technological Forecasting \& Social Change, 94, 350-358.

Hajli, N., Lin, X., Featherman, M., \& Wang, Y. (2014). Social word of mouth: How trust develops in the market. International Journal of Marketing Research, 55(5), 1-17.

Henson, R. K., \& Roberts, J. K. (2006). Use of exploratory factor analysis in published research. Educational \& Psychological Measurement, 66(3), 393-416.

Hew, J. J., Lee, V. H., Ooi, K. B., \& Lin, B. (2016). Mobile social commerce: The booster for brand loyalty? Computers in Human Behavior, 59, 142-154.

Jung, H. J., \& Cho, J. S. (2016). The Effects of Characteristics of Social Commerce have on Customers' Purchase Decisions. The Business and Management Review, 7(3), 8-16. 
Kirk, P. C., Chiagouris, L., \& Gopalakrishna, P. (2012). Some people just want to read: The roles of age, interactivity, and perceived usefulness of print in the consumption of digital information products. Journal of Retailing and Consumer Services, 19, 168-178.

Liang, T. P., \& Turban, E. (2012). Introduction to Special Issue Social Commerce: A Research Framework for Social Commerce. International Journal of Electronic Commerce, 16(2), 5-13.

Morgan, R. M., \& Hunt, S. D. (1994). The commitment-trust theory of relationship marketing. Journal of Marketing, 58, 20-38.

Narakorn, P. (2015). The influence of Flow, Trust in Members, and Social Network Site Identity as Mediating Factors in Interactivity and User Engagement in Online Purchase Group Outcomes and Electronic Loyalty. Bangkok: Ramkhamheang University.

Narakorn, P. (2018). Relationship Quality and Social Support as the Mediating Role Between Social Commerce Constructs and Continuance Intention. Journal of Management Science Chiangrai Rajabhat University, 13(1), 44-65.

Narakorn, P., \& Seesupan, T. (2018). The influence of social network site identity, active control, flow, trust in members and customer loyalty of Facebooks users. Silpakorn University Journal, 38(2), 121-145.

Narakorn, P., \& Seesupan, T. (2018). Trust in Seller Catalyst Social Commerce Construct to Continuance Intention. Journal of Business Administration, 41(159), 24-44.

Nunnally, J. (1978). Psychometric Theory, McGraw-Hill, New York, NY.

Ogara, S. O., Koh, C. E., \& Prybutok, V. R. (2014). Investigating factors affecting social presence and user satisfaction with Mobile Instant Messaging. Commuters in Human behavior, 36, 453-459.

Porter, C. E., \& Donthu, N. (2008). Cultivating trust and harvesting value in virtual communities. Management Science, 54(1), 113-544.

Prahalad, C.K. \& Ramaswamy, V. (2004). Co-creation experiences: the next practice in value creation. Journal of Interactive Marketing, 18(3), 5-14.

Seesupan, T. \& Narakorn (2018). The influence of Social Commerce, Social Support, Satisfaction, Commitment, and Trust to Intention to Co-Creation in Branding and Continuance Intention. Humanities, Arts and Social Sciences Studies, 18(1), 209-235.

Vargo, S., \& Lusch, R. F. (2004). Evolving to a New Dominant Logic for Marketing. Journal of Marketing, 68(1), $1-17$.

Wang, Y., \& Hajli, M. N. (2014). Co-Creation in Branding through Social Commerce: The Role of Social Support, Relationship Quality and Privacy Concerns, Twentieth Americas Conference on Information Systems, Savannah, 1-16.

Yahia, I. B., Al-Neama, I., \& Kerbache, L. (2018). Investigating the drivers for social commerce in social media platforms: Importance of trust, social support and the platform perceived usage. Journal of Retailing and Consumer Services, 41, 11-19.

Zhang, K. Z. K., Benyoucef, M., \& Zhao, S. J. (2016). Building brand loyalty in social commerce: The case of brand microblogs. Electronic Commerce Research and Applications, 15, 14-25.

\section{Copyrights}

Copyright for this article is retained by the author(s), with first publication rights granted to the journal.

This is an open-access article distributed under the terms and conditions of the Creative Commons Attribution license (http://creativecommons.org/licenses/by/4.0/). 